\title{
Influence of low vacuum levels on milking characteristics of sheep, goat and buffalo
}

\author{
Maria Caria, ${ }^{1}$ Carlo Boselli, ${ }^{2}$ Lelia Murgia, ${ }^{1}$ Remo Rosati, ${ }^{2}$ Antonio Pazzona' \\ ${ }^{1}$ Dept. of Agraria, University of Sassari, Italy; ${ }^{2}$ Istituto Zooprofilattico Sperimentale delle Regioni \\ Lazio e Toscana, Roma, Italy
}

\begin{abstract}
Different settings of the operating parameters (pulsator rate, pulsator ratio and vacuum) are used for milking dairy species in different parts of the world. The level of the operating vacuum in machine milking is one of the principal factors which influence the integrity of the tissues and the milk quality. High vacuum levels $(>42 \mathrm{kPa}$ ) are often used to facilitate the opening of the teat canal by overcoming the biological closing forces whithin the teat sphincter, but can result in severe machine-induced teat tissue damage. In this study characteristics and performances of mechanical milking at low vacuum levels have been investigated in different dairy species. Milking times and milk productions have been obtained from milk emission curves, recorded by electronic milk-meters (LactoCorder $\left.{ }^{\circledR}\right)$ during the milking at different vacuum levels of sheep, goats and buffaloes. The results of the comparative experiments clearly indicate that a low vacuum level modifies the kinetics of milk emission, the machine-on time and, thus, the throughput of milking system, in all the dairy species considered. Milk yield was satisfactory at any level tested, showing that low vacuums can be adequate to completely empty the udder. Slight differences were found across species concerning the increase in the milking time per head associated with low levels of milking vacuum Our study represents a contribution to encourage the decrease of the working vacuum during mechanical milking, also for those dairy species generally considered hard to be milked, as buffaloes. Milking
\end{abstract}

Correspondence: Maria Caria, Dept. of Agraria, University of Sassari, viale Italia 39, 07100 Sassari, Italy.

E-mail:mariac@uniss.it

Key words: milking machine, vacuum, sheep, goat, buffalo.

Acknowledgements: this study was supported by grants from the MIURPRIN 2008 "Valutazione di alcune innovazioni per il miglioramento del benessere, dello stato di salute e della qualità produttiva dei ruminanti da latte".

(C) Copyright M. Caria et al., 2013

Licensee PAGEPress, Italy

Journal of Agricultural Engineering 2013; XLIV(s2):e43

doi:10.4081/jae.2013.s2.e43

This article is distributed under the terms of the Creative Commons Attribution Noncommercial License (by-nc 3.0) which permits any noncommercial use, distribution, and reproduction in any medium, provided the original author(s) and source are credited. should be performed applying the lowest vacuum level, compatible with not excessively prolonging milking time, in line with the animal welfare on dairy husbandry.

\section{Introduction}

There are three operative parameters that regulate mechanical milking: working vacuum, pulsator

rate, and pulsator ratio. In general, the parameters of the pulsations are specific for each species of animal, while the vacuum is regulated on the basis of the type of milking system (high and low level) and the customs of the country and area (Billon et al.,1999).

High vacuum levels ( $>42 \mathrm{kPa}$ ) are often used to facilitate the opening of the teat canal by overcoming the biological closing forces whithin the teat sphincter, but can result in severe machine-induced teat tissue damage. These vacuum levels seem to be extremely high when compared with the vacuum needed to open the teat canal in Sarda sheep (26 kPa), Lacaune sheep (25.0 to $35.9 \mathrm{kPa}$; Marnet et al., 1999), the mountain Greek breed Boutsiko (16.59 kPa; Sinapis et al., 2007), Saanen goats (34.6 kPa; Le Du and Benmederbel, 1984), and buffaloes (over $30 \mathrm{kPa}$; Aliev, 1969).

High vacuum levels can cause several undesirable effects in small ruminants, such as an increase in somatic cell count (Sinapis and Vlachos, 1999; Le Du, 1983, 1985; Pazzona and Murgia, 1993) even when combined with a low pulsator rate (Fernandez et al., 1999). By contrast, Peris et al. (2003) reported that in the short term neither somatic cell count of the milk nor teat thickness changes were affected by differences in vacuum level ( $36 \mathrm{vs.} 42 \mathrm{kPa}$ ). It is well known that application of the vacuum slows blood circulation in the teat tissue, thus influencing its temperature. Recent studies (Stelletta et al., 2007) have shown that the teat returns to its normal physiological temperature more rapidly if the milking vacuum is reduced. Increase in milking time and increased frequency of the teatcups falling off are the principal negative factors that have up to now discouraged the use of low vacuum (Spencer and Rogers, 1991). In recent years, there has been a tendency to reduce the vacuum level used for milking small ruminants (34 tom $36 \mathrm{kPa}$ ). In Sardinia, most systems used for milking sheep and goats operate at vacuum levels between 41 and $44 \mathrm{kPa}$, with a maximum level of $50 \mathrm{kPa}$ (Pazzona and Murgia, 2003).

A positive relationship between increasing working vacuum and the milk SCC has been found in buffalo (Badran, 1992; Pazzona and Murgia, 1992), which confirms preceding works on cows where raising the vacuum from 33 to over $50 \mathrm{kPa}$ had a negative effect on teat condition (Langlois et al., 1980) and increased mastitis incidence (Galton and Mahle, 1980; Langlois et al., 1980; Osteras and Lund, 1988). By contrast, increase in milking time and increased frequency of the teat cups falling off are the principal negative factors caused by lowering the milking vacuum level (Spencer and Rogers, 1991). Because little or 
no cisternal milk is available in buffalos, the animals are often exposed to a long period of vacuum without any ejection of milk. The use of high-working vacuums combined with the absence of milk can cause irritation in the delicate mammary tissues and, thus, stress the animals (Bruckmaier and Blum, 1996).

Buffalo are considered to be slow and hard milkers (Sastry et al., 1988) because of their slow milk ejection reflex and their sphincter muscle around the streak canal is thicker than in cattle (Stahl Hogberg and Lind, 2003). For these reasons the working vacuum applied to buffalo is generally higher than the level used in cows so as to shorten the milking time. In a recent field survey carried out in 189 installations for buffalo milking in Italy, the working vacuum levels varied from 40 to 53 $\mathrm{kPa}$. The most frequent values (45\%) ranged between 44 and $46 \mathrm{kPa}$, whereas only $4 \%$ of the installations were set at $\geq 50 \mathrm{kPa}$ (Assaociazione Italiana Allevatori in 2009, Rome, Italy, personal communication) .

In line with the current interest in animal welfare, this study investigates characteristics and performances of mechanical milking at low vacuum levels in dairy. sheep, goats and buffaloes.

\section{Materials and methods}

\section{Sheep}

A prototype milking system specifically designed to optimize vacuum stability and allow low vacuum milking was used in the experiment. The milking parlor prototype was one platform with 24 sequentially gated stalls, with 12 milking units in a low line system. The technical innovation of the prototype is the internal diameter of the milk line, 74 $\mathrm{mm}$ instead of $50 \mathrm{~mm}$ normally used for sheep (UNI 11008, 2002). The greater diameter of the milk line optimizes the flow conditions even when air suddenly enters, a very common event during sheep milking due to the short milking time for this species (Pazzona and Murgia, 1997). Stabilizing the vacuum in the milking system minimizes the possibility of the clusters falling off (Pazzona and Murgia, 2001). The milking units were assembled from different types of components, chosen taking into consideration both the suitability of the teatcups for the flock and the total mass of the components. This mass was $490 \mathrm{~g}$, the average mass for clusters commonly used in sheep milking, which vary between 390 and $640 \mathrm{~g}$ in mass based on our own survey of eight commercial units. The experiment was carried out on 48 pluriparous Sarda breed sheep. The animals were randomly divided into two groups of 24, and one group was assigned the working vacuum of $28 \mathrm{kPa}$ while the other was assigned the $42 \mathrm{kPa}$. Milking was performed twice daily at 6.00 a.m., and 6.00 p.m.; for the trial the data was recorded one time a day for three months, at the afternoon milking. During the experiment, the operator's work time for each sheep was measured, including access time and downtime. The milking routine was performed by two operators, each of whom managed six milking units. From these data, the throughput of the milk installation, in terms of sheep milked per hour and sheep milked per man hour, was calculated for both low vacuum and standard vacuum (Pazzona et al., 2009). The milking routine did not include any form of preparation of the udder or mechanical stripping.

\section{Goats}

Comparative tests were carried out to evaluate the effect of the two operative vacuum levels during milking of goats (35 and $44 \mathrm{kPa}$ ). Forty Camosciata breed goats were milked in the experiment, using a bucket milking system equipped with two milking units. The data obtained from the test were then used to simulate the milking routine applied in a 12 stalls in a low-line system, equipped with 12 milking units and automatic cluster removal. The throughput of the milking installation and the operator performance, was calculated for both vacuum levels tested, using the mathematical model developed by Caria et al. (2011).

\section{Buffalo}

A herd of 450 milking Mediterranean breed buffalo, in different parity and stage of lactation, were used in the experiment. The milking system was a $2 \times 28$ parallel parlor with a low-level milking system equipped with a light-weight (1.80 kg) cluster (Harmony Plus, DeLaval, Tumba, Sweden), automatic cluster removers, and electronic herd management system (Alpro system, DeLaval). The cluster was equipped with conic rubber liners and the pulsator rate was set at 60 cycles/min and $65 \%$ ratio. The working vacuum was tested for values of $42 \mathrm{kPa}$ and $36 \mathrm{kPa}$. Milking took place at intervals of $9 \mathrm{~h}$ (daytime) and $15 \mathrm{~h}$ (overnight). The milking routine involved the attachment of the milking unit, without any preparation of the udder either by pre-stimulation or pre-dipping, and the manual removal of the teat cups without mechanical or manual stripping. During milking the animals were not given any concentrates. The operator work time for each buffalo was measured, including access time and idle/waiting times. These data allowed us to calculate the throughput of the milking system and the operator performance at vacuums of 36 and $42 \mathrm{kPa}$ (Caria et al., 2011).

\section{Equipment used and statistical analysis}

For all the experiments carried on, the milking time (the time from attaching to removing the teat cups) and the milk yield were recorded using electronic mobile milk flow meter (Lactocorder®, WMB, Balgach, Switzerland).

Statistical analysis was carried out by comparing the milking time and milk yield between low vacuums and standard vacuums, using a Mann Whitney $U$ test from SPSS (ver. 15.0, Chicago, Ill.: SPSS, Inc.).

\section{Results and discussion}

Table 1 reports the statistics on milking performances of all the dairy species investigated.

The tests on ewe milking have shown no significative differences on milk production $(0.49 \mathrm{~kg})$ when milking at 42 and $28 \mathrm{kPa}$, while milking time increased $(\mathrm{P}<0.01)$ passing from $0.94 \mathrm{~min}$ to $1.10 \mathrm{~min}(+17 \%)$. This is due to the lower pressure difference across the teat canal exerted by the teatcups on the udder, that lowers the milk flow rate through the teat, prolonging the milking time.

The delay of the milking time for an individual ewe obtained using the vacuum of $28 \mathrm{kPa}$ do not affect so consistently the total session milking time, when the operator managing 6 milking units. The throughput of milking system obtained by specific equations (Pazzona et al., 2009) shows a little difference between the two levels of vacuum: $333 \mathrm{sheep} / \mathrm{h}$ at $42 \mathrm{kPa}$ s 321 at $28 \mathrm{kPa}$ (Table 2).

In goats, in contrast to what is observed in ewes, both the time and the milk produced per milking were increased when lowering the vacuum from 44 to $35 \mathrm{kPa}$. As a consequence, also for this specie the throughput of the milking system, equipped with automatic cluster removals, as hypothesized in this study, resulted lower than 12 goats/h $(-7 \%)$ using the vacuum of $35 \mathrm{kPa}$ (Table 2). The difference between the average milk yield/goat per milking was statistically different at the two vacuum levels: $1.24 \mathrm{~kg}$ at $35 \mathrm{kPa}$ and $1.05 \mathrm{~kg}$ at $44 \mathrm{kPa}$ ). These values could be interpreted as the longer milking time due to low vacuum level allows to remove both the cisternal and alveolar milk.

The response of buffaloes to the decrease in milking vacuum was 
Table 1. Mean milk production and milking time per all dairy species studied for 2 vacuum levels tested.

\begin{tabular}{|c|c|c|c|c|c|c|c|c|c|}
\hline \multirow[b]{2}{*}{ Vacuum (kPa) } & \multicolumn{2}{|c|}{ Sheep } & \multirow{2}{*}{$\begin{array}{l}\text { P } \\
-\end{array}$} & \multicolumn{2}{|c|}{ Goat } & \multirow{2}{*}{$\begin{array}{l}P \\
-\end{array}$} & \multicolumn{2}{|c|}{ Buffalo } & \multirow{2}{*}{$\begin{array}{l}P \\
-\end{array}$} \\
\hline & 28 & 42 & & 35 & 44 & & 36 & 42 & \\
\hline $\mathrm{N}$ & 108 & 117 & - & 335 & 323 & - & 192 & 288 & - \\
\hline Milk yield (kg) & 0.49 & 0.49 & N.S. & 1.24 & 1.05 & $<0.01$ & 3.6 & 4.1 & N.S. \\
\hline SE & 0.01 & 0.01 & - & 0.02 & 0.02 & - & 0.15 & 0.14 & - \\
\hline Milking time (min) & 1.10 & 0.94 & $<0.01$ & 2.51 & 2.13 & $<0.01$ & 8.13 & 7.36 & $<0.01$ \\
\hline SE & 1.61 & 1.49 & - & 0.04 & 0.04 & - & 0.34 & 0.24 & - \\
\hline
\end{tabular}

similar to ewes. Comparison of the milk yield was not statistically different at the two vacuum levels (Table 1). The average values obtained during our tests, $3.6 \mathrm{~kg} /$ milking at $36 \mathrm{kPa}$ and $4.1 \mathrm{~kg} /$ milking at $42 \mathrm{kPa}$, mirror the data recorded in previous studies (Bava and Zucali, 2007; Borghese et al., 2007). The high variability in individual milk production was related to the presence of animals at different stages of lactation.

During the whole milking session, the duration of each phase of the routine was analyzed, to define the operator performance and the milking system throughput as a function of the individual milking time at the working vacuums of $36 \mathrm{kPa}$ and $42 \mathrm{kPa}$ (Table 2). The optimal number of milkers is calculated to ensure the presence of the operator at the end of milking of the first buffalo that has had the clusters attached.

Referring to the $28+28$ stalls milking system and to the results obtained from the milk curves, the model was applied to a milking routine without pre-stimulation or post-milking treatment, stripping of the udders, and the use of automatic cluster removers set at $0.20 \mathrm{~kg} / \mathrm{min}$. Considering 2 milkers, the total herd milking time resulted in $3.25 \mathrm{~h}$ at $42 \mathrm{kPa}$ of vacuum and $3.36 \mathrm{~h}$ at $36 \mathrm{kPa}$, corresponding to a throughput of the milking system $(\mathrm{Co})$ of 139 and 134 buffalo/h, respectively. Operator performance $(P)$ is 69 buffalo/man-hour, at a vacuum of 42 $\mathrm{kPa}$ and $67 \mathrm{buffalo} / \mathrm{man}^{*}$ hour at a vacuum of $36 \mathrm{kPa}$, with a difference of 2 buffalo/man*hour.

These results clearly showed that even a vacuum of $36 \mathrm{kPa}$ is more than enough to guarantee that the teat canal opens. By contrast there was a significant increase in milking time $(0.77 \mathrm{~min})$ due to a longer latency time and a prolonged time for the complete emptying of the udder. Anyhow, this aspect should be taken into account considering that the duration of milking in cows seems to influence teat tissue reactions less than the high vacuum (Hamann et al., 1993). In farms where the latency time could be shortened by inducing milk let down through pre-stimulation of the udders along with feeding concentrate in parlor, the use of a low milking vacuum level might represent an appropriate choice, considering the advantages which it offers in terms of animal health and well-being.

\section{Conclusions}

The results of the study concerning the effects of dairy milking at low vacuum levels on both milk emission parameters and milking parlour throughput showed that:

- Considerations concerning the effect of vacuum setting on the milking time and consequently the throughput of the milking system, are similar for all three dairy species examined.

- The milking time for small ruminants increased on average by 17.0 $-17.8 \%$ using the lower levels of vacuum. In buffalo the milking time
Table 2. Throughput of milking system and operator performance at different vacuum levels as a function of the routine.

\begin{tabular}{lcccccc} 
& \multicolumn{2}{c}{ Sheep $^{1}$} & \multicolumn{2}{c}{ Coat $^{2}$} & \multicolumn{2}{c}{ Buffalo $^{3}$} \\
Vacuum (kPa) & 28 & 42 & 35 & 44 & 36 & 42 \\
Co (heads/h) & 321 & 333 & 152 & 164 & 134 & 139 \\
\hline P (heads/man*h) & 161 & 166 & 152 & 164 & 67 & 69 \\
\hline
\end{tabular}

$\mathrm{C}_{0}=$ throughput of the milking system; $\mathrm{P}=$ operator performance. ${ }^{1}$ Two milkers; ${ }^{2} \mathrm{One}$ milker; ${ }^{3} \mathrm{Tw}$ milkers.

increased by just $10.5 \%$, probably because of the difference between the vacuum levels tested, that was $6 \mathrm{kPa}$ for this specie instead of 14 and $9 \mathrm{kPa}$, respectively for sheep and goats.

- As a consequence, the efficiency of milking routine was also influenced by the level of working vacuum. When reduced, it slightly affected the throughput of milking system and the operator performance. The Co was decreased of about 12 heads/h, corresponding to 3.6 and $7.3 \%$ for sheep and goats respectively. In buffalo milking, the Co was reduced of about $3.6 \%$, corresponding to about 7 minutes increase in the time spent for the whole milking session. This short time does not compromise the management of the milking and the farm labour organization, considering that the use of automatic cluster removal strongly reduces the milking time.

- The results obtained show that the choice of setting the milking vacuum at a lower level than those commonly used, for all the species investigated, is not compromised by the slight decrease of throughput, especially if the amount of milk yield per milking is the same as found in sheep and buffalo or even higher $(+18 \%, \mathrm{P}<0.01$, in goats).

\section{References}

Aliev, M. G. 1969. Physiology of machine milking of buffaloes. Dairy Science Abstr. 32:329-332.

Badran, A.E.1992. Effect of vacuum and pulsation rate on milking ability in Egyptian buffaloes. Buffalo J. 1:1-7.

Bava L., Zucali M. 2007. Una buona mungitura con una giusta routine. Informatore Zootecnico 18:156-169.

Billon P., Ronningen 0., Sangiorgi F., Schuiling E. 1999. Quantitative requirements of milking installations for small ruminants: Survey in different countries. In Proc. 6th Intl.Symposium in Machine Milking of Small Ruminants: Milking and Milk Production of Dairy Sheep and Goats, 209-215.

Borghese A., Mazzi M., Rosati R., Boselli C. 2007. Milk flow pictures in Mediterranean Italian buffaloes, through LactoCorder instrument. pp 60-63 in Proc. Int. Symp. Teagasc/IDF on advances in milking, Cork, Ireland. 
Bruckmaier R. M., Blum J. W. 1996. Simultaneous recording of oxytocin release, milk ejection and milk flow during milking of dairy cows with and without prestimulation. J. Dairy Res. 63:201-208.

Caria M., Murgia L., Pazzona A. 2011. Effects of the working vacuum level on mechanical milking of buffalo. J. Dairy Sci. 94: 1755-1761.

Fernandez N., Diaz J. R., Peris C., Rodriguez M., Molina M. P., Torres A. 1999. Machine milking parameters for the Manchega sheep breed. Pages 233-238 in Proc. Sixth International Symposium in Machine Milking of Small Ruminants, Athens, Greece. European Association for Animal Production (EAAP) Publication no. 95. Wageningen Academic Publishers, Wageningen, the Netherlands.

Galton D. M., Mahle D. E. 1980. Effects of vacuum level and pulsation ratio on udder health. Proc. Annu. Mtg. Nat. Mastitis Council Inc. 19:39-43.

Hamann J., Mein G. A., Wetzel S. 1993. Teat tissue reactions to milking: Effects of vacuum level. J. Dairy Sci. 76:1040-1046.

Langlois B. E., Cox J. C., Hemken R. W., Nicolai J. 1980. Effect of milking vacuum on some indicators of bovine mastitis. J. Dairy Sci. 63(Suppl. 1):116-117.

Le Du J. 1983. Comparaison d'un lactoduc en ligne haute et en ligne basse: Incidence sur la traite des brebis de races Lacaune et Manech. Ann. Zootech. 32: 43-52.

Le Du J., Benmederbel B. 1984. Aptitude des chevres de race Saanen a la traite mecanique: Relation avec les caracteristiques physiques du trayon. Ann. Zootech. 33: 375-384.

Le Du J. 1985. Parametres de fonctionnement affectant l'efficacite des machines a traire pour brebis et chevres. Pages 430-431 in 36eme Reunion Annuelle F.E.Z., Ed. Giahoudi Bros Publication, Thessalonique, Grece.

Marnet P. G., Combaud J. F., Dano Y. 1999. Relationships between characteristics of the teat and milkability in Lacaune sheep. In Proc. 6th Intl. Symposium in Machine Milking of Small Ruminants: Milking and Milk Production of Dairy Sheep and Goats, 41-44

Osteras 0., Lund A. 1988. Epidemiological analyses of the associations between bovine udder health and milking machine and milking management. Prev. Vet. Med. 6:91-108.

Pazzona A., Murgia L. 1992. Effect of milking vacuum on leucocyte count in buffalo milk. Pages 691-694 in Proc. 24th International Conference on Agricultural Mechanization, Zaragoza, Spain.

Pazzona A., Murgia L. 1993. Effetto del vuoto di mungitura e delle fre- quenze di pulsazione sulla carica leucocitaria del latte di pecora. L'Informatore Agrario 42:43-46.

Pazzona A., Murgia L. 1997. Dimensionamento e prestazioni del lattodotto nelle mungitrici per ovini. L'informatore Agrario 8: 8993.

Pazzona A., Murgia L. 2003. Stato attuale degli impianti per la mungitura di ovini e caprini. Informatore Zootecnico, Supp. No.12: 42-50.

Pazzona A., Caria M., Murgia L. 2009. Effects of a low vacuum level on vacuum stability and milking parlor performance for sheep. Trans. ASABE 52:247-252.

Peris C., Diaz J. R., Balasch S., Beltran M. C., Molina M. P., Fernandez N.. 2003. Influence of vacuum level and overmilking on udder health and teat thickness changes in dairy sheep. J. Dairy Sci. 86(12): 38913898.

Sastry N. S. R., Bhagat S. S., Bharadwaj A. 1988. Aspects to be considered in milking management of buffaloes. Indian J. Anim. Prod. Manag. 4:378-393.

Sinapis E., Vlachos I. 1999. Influence du niveau de vide de la machine a traire et des facteurs zootechniques sur le comptages de cellules somatiques chez les chevres locale grecque. Pages 513-518 in Proc. Sixth International Symposium in Machine Milking of Small Ruminants, Athens, Greece. European Association for Animal Production (EAAP) Publication no. 95. Wageningen Academic Publishers, Wageningen, the Netherlands.

Sinapis E., Marnet P. G., Skapetas B., Hatziminaoglou I. 2007. Vacuum level for opening the teat sphincter and the change of the teat end wall thickness during the machine milking of mountainous Greek breed (Boutsiko) sheep. Small Rumin. Res. 69(1/3): 136-143.

Spencer S. B., Rogers G. W. 1991. Effect of vacuum and milking machine liners on liner slip. J. Dairy Sci. 74:429-432.

Stahl Hogberg M., Lind 0. 2003. Milking the buffalo. Buffalo milk production. Ari. Lic. Animal Husbandry, Department of Nutrition and Management, Sweden.

Stelletta C., Murgia L., Caria M., Gianesella M., Pazzona A., Morgante M. 2007. Thermographic study of the ovine mammary gland during different working vacuum levels. In Proc. ASPA XVII Congress. Italian J. Animal Sci. 6(supp. 1): 600.

UNI 11008. 2002. Impianti per la mungitura meccanica delle specie ovina e caprina. Milan, Italy: Ente Nazionale Italiano di Unificazione. 